\title{
Okultne prakse, demonski sindrom i mračna trijada ličnosti
}

\author{
Zlatko Šram*
}

\begin{abstract}
Sažetak
U ovom smo istraživanju nastojali empirijski utvrditi (a) povezanost između okultnih praksi i demonskoga sindroma te (b) povezanost izmedu mračne trijade ličnosti (makijavelizma, narcizma i psihopatije), okultnih praksi i demonskoga sindroma. Istraživanje je provedeno na prigodnom uzorku punoljetnih Hrvata u Vojvodini $(N=189)$. Radi ovoga istraživanja konstruirane su skale za mjerenje okultnih praksi i demonskoga sindroma. Mračna trijada ličnosti mjerena je upitnikom SD3 (Jones i Paulhus, 2014). Utvrdili smo da se okultne prakse i demonski sindrom nalaze u supstancijalnoj korelaciji $(r=0,57)$ te da se sve tri dimenzije mračne trijade nalaze u znatno većim pozitivnim korelacijama s okultnim praksama negoli s demonskim sindromom. Izgleda da demonski sindrom ima drugačiju psihopatološku pozadinu koju valja istražiti u budućim istraživanjima.
\end{abstract}

Ključne riječi: okultne prakse, demonski sindrom, duševni poremećaji, mračna trijada ličnosti, Hrvati u Vojvodini

\section{Uvod}

\subsection{Okultne prakse i demonski sindrom}

Teško je naći istraživanja u znanstvenim psihološkim, psihijatrijskim i teološkim časopisima u kojima bi se empirijski ispitivala povezanost okultnih praksi i duševnoga poremećaja koji ukazuje na prisutnost subjektivnoga osjećaja demonskoga utjecaja, uznemiravanja i kontrole. U znanstvenoj literaturi još se mogu

* Dr. sc. Zlatko Šram, viši znanstveni suradnik, Hrvatski centar za primijenjena društvena istraživanja. Adresa: Hanamanova 7, 10000 Zagreb, Hrvatska. E-adresa: zlatko.sram@appliedsocresearch.com. Ovo je istraživanje provedeno u okviru znatno širega sociološkoga i socijalno-psihološkoga istraživanja pod nazivom Nacionalni identitet, društveni svjetonazori i izloženost masovnim medijima kod Hrvata u Vojvodini. Istraživanje je provedeno u okviru znanstvene djelatnosti Hrvatskoga akademskoga društva u Srbiji sa sjedištem u Subotici. Središnji državni ured za Hrvate izvan Republike Hrvatske dao je financijsku potporu za ovaj istraživački projekt, koji je vodila dr. sc. Jasminka Dulić. Autor ovoga članka bio je suautor u koncepciji modela istraživačkoga projekta koji je proveden ujesen 2018. godine na teritoriju Autonomne pokrajine Vojvodine. Izvorni podatci istraživanja unijeti su u SPSS programu i dostupni su na zahtjev zainteresiranim istraživačima. 
naći istraživanja koja se odnose na povezanost okultnih ili paranormalnih vjerovanja i interesa s duševnim poremećajima (Nie i Olson, 2016, 512), ali teško je naći istraživačke radove koji se bave povezanošću okultnih praksi s duševnim poremećajem koji u svojoj psihološkoj podlozi ima subjektivni osjećaj demonske prisutnosti.

Sa znanstveno-pozitivističkoga i svjetonazorski materijalističkoga stajališta, pojavljuje se problem ontološke naravi u pogledu povezanosti okultnih praksi $^{1}$ i prisutnosti demonskoga sindroma. ${ }^{2}$ Postavlja se naime pitanje jesu li okultni fenomeni stvarni ili nisu, odnosno postoji li povezanost između okultnih praksi i djelovanja zlih duhovnih entiteta i snaga koji se očituju u subjektivnom osjećaju demonske prisutnosti (Hunter, 2015, 16-17). ${ }^{3}$ Čini se kako je izučavanje okultnih praksi, a u čijoj se pozadini pretpostavlja demonska prisutnost i utjecaj, još uvijek tabu tema u znanstvenim psihološkim i psihijatrijskim istraživanjima. I to unatoč činjenici da se psihoterapeuti, katolički svećenici i pastori drugih kršćanskih denominacija suočavaju s ljudskim patnjama koje se često ne mogu sasvim razumjeti, a mogu biti rezultat okultnih praksi. Unatoč tomu što se u najnovijem, petom izdanju Dijagnostičkoga i statističkoga priručnika za duševne poremećaje Američke psihijatrijske udruge spominje da u sklopu disocijativnoga poremećaja identiteta može biti stanje koje neki ljudi opisuju kao iskustvo opsjednutosti (possession) ${ }^{4}$ koje se »manifestira kao ponašanje koje izgleda kao da je ‘duh', natprirodno biće ili nešto izvan osobe preuzelo kontrolu« (Američka psihijatrijska udruga, 2014, 293). Psiholozi i psihijatri rijetko kad razmatraju posljedice koje imaju ili mogu imati okultne prakse na duševno zdravlje pojedinca te ih stoga ne uzimaju ozbiljno u dijagnosticiranju duševnoga poremećaja i planiranju terapeutskoga pristupa pojedincu sa specifičnim duševnim tegobama (Morabito, 2015, 11). Malo se naime pozornosti posvećuje mračnomu području duhovnoga života i duhovnim problemima uzrokovanim okultnim praksama.

Smatrali smo stoga kako postoji potreba za jednim empirijskim istraživanjem kojim će se moći utvrditi odnos između okultnoga i demonskoga. Drugim riječima, od izuzetne je važnosti, kako sa psihološko-psihijatrijskoga, tako i s katoličkoga pastoralnoga stajališta, biti u mogućnosti dijagnosticirati obrazac okultno posredovanoga duševnoga poremećaja čija klinička slika upućuje na prisutnost subjektivnoga doživljaja demonskoga djelovanja, utjecaja i kontrole. Pošli smo sa

1 Vračanje, magija i spiritizam odrednice su okultnoga prostora kako smo ga definirali u ovom radu.

2 Subjektivni osjećaj unutarnje prisutnosti zla i mračnih sila koje kontroliraju život pojedinca jest psihološko-duhovni sadržaj demonskoga sindroma kako smo ga definirali u ovom radu.

3 U kršćanskoj se demonologiji eksplicite navodi kako su okultne prakse pod utjecajem demonskih sila (Jeanguenin, 2010, 7).

4 Zanimljivo je primijetiti kako u hrvatskom prijevodu DSM-5 Naklade Slap prevoditelj rečenični sklop koji na engleskom jeziku glasi an experience of possession (American Psychiatric Association, 2013, 292) prevodi kao »iskustvo obuzetosti« (Američka psihijatrijska udruga, 2014, 292). Očigledno je hrvatski prevoditelj htio izbjeći svaku religioznu konotaciju koju ima riječ opsjednutost, jer ona redovito implicira demonsko opsjednuće. Značenje hrvatske riječi obuzetost ni u kojem slučaju ne odgovara značenju engleske riječi possession u kontekstu disocijativnoga poremećaja kako se tretira u DSM-5 jer se possession eksplicite odnosi na prisutnost duhovnoga ili nadnaravnoga entiteta koje je izvan osobe preuzelo kontrolu. 
stajališta da svijet okultnih praksi predstavlja »pravu religiju Sotone « (Amorth, 2005, 42) i da je »blizak sotonskomu kraljevstvu « (Mezzetti, 2016, 108). ${ }^{5} \mathrm{Za}$ očekivati je stoga kako bavljenje okultnim praksama može uzrokovati demonskoinducirane psihičke i duhovne bolesti (Campos, 2018, 45; Jeanguenin, 2010, 39). Međutim, subjektivni osjećaj demonske prisutnosti i utjecaja ne mora nužno biti povezan s okultnim praksama. Naime, određeni simptomi demonskoga sindroma mogu biti posljedica različitih drugih uzroka, kao što je primjerice tvrdokorno ustrajavanje u stanju grijeha (Amorth, 2006, 47-48), traumatska iskustva u djetinjstvu (MacNutt, 2005, 85) ili pak simptomi određene duševne bolesti (Američka psihijatrijska udruga, 2014, 292-293).

Prostor okultnih praksi u ovom istraživanju definiraju prisustvovanje vještičarenju ili vudu ceremoniji, prisustvovanje seansama na kojima se zazivaju duhovi mrtvih, posjećivanje osobe koja proriče budućnost iz karata, listića čaja, dlana, kristalne kugle i slično te igranje s Ouija pločom za prizivanje duhova, tarot kartama ili igrom Tamnice i zmajevi. Prostor demonskoga sindroma definiraju prisutnost osjećaja da se neka mračna sila dočepala osobe i prisilila ju da radi loše stvari koje nije htjela, prisutnost osjećaja da se neke mračne sile kreću unutar osobe, osjećaj prisutnosti zla koje upravlja životom osobe i utječe na njezine misli i ponašanje te prisutnost osjećaja da je neko zlo povezano s osobom.

\subsection{Mračna trijada ličnosti}

U ovom smo istraživanju također nastojali utvrditi psihološku pozadinu okultnih praksi i demonskoga sindroma koristeći se konceptom mračne trijade ličnosti, koja u svojoj strukturi sadrži makijavelizam, narcizam i psihopatiju, dakle tri socijalno averzivne, zlokobne i destruktivne crte ličnosti (Jones i Paulhus, 2014, 28; Paulhus i Williams, 2002, 556). Makijavelizam je osobina koja ukazuje na izrazito manipulativnu osobu, dvoličnu u interpersonalnim odnosima, koja izražava cinični prijezir prema moralnosti i snažno je usmjerena na vlastiti interes i probitak (Jones i Paulhus, 2009, 97-99). Narcizam karakterizira osjećaj vlastite veličine, dominacije i superiornosti, predstavlja kombinaciju taštine i egocentričnoga obožavanja vlastitih kvaliteta (Muris et al., 2017, 184). Psihopatija ukazuje na prisutnost antisocijalnoga ponašanja, osvetoljubivost, odsutnost empatije i grižnje savjesti, snažnu potrebu za podražajima, nemogućnost kontroliranja vlastitih impulsa, impulzivnost i emocionalnu hladnoću (Muris et al., 2017, 184). Ukratko, sve tri dimenzije mračne trijade ukazuju na socijalno zlokobni (malevolent) karakter usmjeren prema samopromociji, na prisutnost emocionalne hladnoće, dvoličnost, lažljivost i agresivnost (Paulhus i Williams, 2002, 557).

Mračna trijada u različitim se istraživanjima pokazala u povezanosti s onim oblicima ponašanja koji ukazuju na varanje, neiskrenost, nepoštenje, odsutnost poniznosti (Lee i Ashton, 2014, 2-5) i s različitim rizičnim i kriminalnim oblicima ponašanja (Azizli et al., 2016, 37). Međutim, nismo naišli ni na jedno istraživanje koje bi dovodilo u vezu mračnu trijadu s okultnim praksama ili subjektivnim

5 Upravo se suradnja čovjeka i Sotone odvija preko okultnoga (Jeanguenin, 2010, 25). 
osjećajem demonske prisutnosti. A bavljenje okultnim praksama zasigurno je rizičan i neprilagođen oblik ponašanja koji se reflektira kako na psihološkoj tako i na duhovnoj razini. Upravo ovim istraživanjem pokušavamo popuniti prazninu koja postoji u području istraživanja povezanosti mračne trijade, okultnih praksi i demonskoga sindroma.

\subsection{Ciljevi i hipoteze istraživanja}

Polazeći od povezanosti okultnih praksi i demonskoga utjecaja u katoličkoj demonologiji (Fortea, 2018, 67; Jeanguenin, 2010, 7), u ovom smo istraživanju nastojali utvrditi postoji li i u kojoj mjeri u realnom psihološkom prostoru povezanost između okultnih praksi i demonskoga sindroma kako smo ga definirali u ovom istraživanju. Pretpostavili smo postojanje pozitivne korelacije između okultnih praksi i demonskoga sindroma u realnom psihološkom prostoru.

Imajući u vidu kako makijavelizam, narcizam i psihopatija predstavljaju zlokobnu (malevolent) stranu ljudske prirode (Muris et al. 2017, 192), nastojali smo utvrditi povezanost dimenzija mračne trijade s okultnim praksama i demonskim sindromom. Pretpostavili smo da se dimenzije mračne trijade nalaze u pozitivnoj korelaciji s okultnim praksama i demonskim sindromom.

\section{Metoda}

\subsection{Ispitanici i postupak}

Istraživanje je provedeno na prigodnom uzorku punoljetnih ispitanika hrvatske nacionalnosti u Vojvodini: u Bačkom Bregu, Novom Sadu, Somboru, Sonti, Subotici, Surčinu i Šidu (N = 189). ${ }^{6}$ U uzorku je bilo $48 \%$ muških ispitanika. U Tablici 1 vidimo da su ispitanici ravnomjerno zastupljeni u svim dobnim skupinama: srednja vrijednost dobi ispitanika bila je $M=45,07$ godina, $S D=16,01$. $S$ obzirom na školsku naobrazbu uzorak ispitanika zakrivljen je prema višim stupnjevima naobrazbe (Tablica 2). U 97\% slučajeva ispitanici su se deklarativno izjasnili kao pripadnici Rimokatoličke crkve. Ispitanici su samostalno ispunjavali upitnik koji bi im anketari uručili sa zamolbom za sudjelovanjem u istraživanju.

Tablica 1. Dob ispitanika

Table 1. Age of examinee

\begin{tabular}{|l|l|}
\hline \multicolumn{1}{|c|}{ Dob } & \multicolumn{1}{c|}{ Udio } \\
\hline $18-28$ godina & $20,1 \%$ \\
\hline $29-40$ godina & $19 \%$ \\
\hline $41-50$ godina & $22,2 \%$ \\
\hline $51-60$ godina & $19 \%$ \\
\hline 61 i više godina & $19,6 \%$ \\
\hline
\end{tabular}

6 Pripadnici različitih hrvatskih udruga u navedenim gradovima i mjestima proveli su anketiranje ispitanika za koje su znali ili pretpostavljali da su hrvatske nacionalnosti. Uzorak na kojem je istraživanje provedeno može se smatrati prigodnim i slučajnim. 
Tablica 2. Formalno obrazovanje

Table $2 . \quad$ Formal education

\begin{tabular}{|l|l|}
\hline \multicolumn{1}{|c|}{ Obrazovanje } & \multicolumn{1}{c|}{ Udio } \\
\hline Osnovna škola & $5,8 \%$ \\
\hline Trogodišnja strukovna škola & $14,8 \%$ \\
\hline Četvorogodišnja srednja škola & $34,9 \%$ \\
\hline Viša škola & $12,7 \%$ \\
\hline Fakultet & $31,7 \%$ \\
\hline
\end{tabular}

\subsection{Mjerni instrumenti}

Skalu za mjerenje okultnih praksi i skalu za mjerenje demonskoga sindroma konstruirali smo na temelju izbora specifičnih oblika okultnih praksi i subjektivnoga doživljaja demonske prisutnosti koji se navode u kršćanskoj literaturi (usp. Immanuel, 2016). Konstruktnu validnost tih skala provjerili smo faktorskom analizom pod komponentnim modelom, unutarnju pouzdanost skala izračunali smo pomoću Cronbachova koeficijenta alfa, a homogenost skala provjerili smo izračunavanjem prosječne korelacije između čestica koje definiraju pojedinu skalu.

Skala za mjerenje okultnih praksi sadržavala je 4 čestice. Od ispitanika je traženo da odgovore na pitanje: Koliko često ste radili sljedeće stvari? Odgovore su davali na skali Likertova formata: $1=$ nikada, $2=$ rijetko, $3=$ ponekad, $4=$ često i 5 = veoma često. Faktorska analiza skale od 4 čestice rezultirala je jednofaktorskom solucijom, kojom je objašnjeno 61,39\% varijance (Tablica 3). Tu latentnu dimenziju nazvali smo Okultne prakse i transformirali ju u kompozitnu varijablu te izračunali pouzdanost i homogenost skale. Cronbachova alfa iznosila je 0,76 , a prosječna korelacija između svih čestica koje formiraju skalu iznosila je $\mathrm{r}=0,48$. Možemo stoga zaključiti kako je skala Okultne prakse unutarnje pouzdani i homogeni mjerni instrument koji sadržava prakticiranje vračanja, magije, spiritizam i prizivanje duhova.

Skala za mjerenje demonskoga sindroma također je sadržavala 4 čestice. Od ispitanika je traženo da odgovore na pitanje: Koliko često ste osjećali sljedeće stvari? Odgovore su davali na skali Likertova formata: $1=$ nikada, $2=$ rijetko, 3 $=$ ponekad, 4 = često i 5 = veoma često. Faktorska analiza skale od 4 čestice rezultirala je jednofaktorskom solucijom kojom je objašnjeno 70,53\% varijance. Tu latentnu dimenziju nazvali smo Demonski sindrom i transformirali ju u kompozitnu varijablu. Veličina Cronbachova koeficijenta (alfa $=0,83)$ i veličina prosječne korelacije između svih čestica koje definiraju tu skalu $(\mathrm{r}=0.60)$ pokazali su da je skala Demonski sindrom unutarnje pouzdani i homogeni mjerni instrument koji ukazuje na subjektivni osjećaj prisutnosti zla i mračnih sila koje kontroliraju život pojedinca. Veličina korelacije između Okultnih praksi i Demonskoga sindroma iznosila je $\mathrm{r}=0,57$ 
Tablica 3. Faktorska analiza skale Okultne prakse

Table 3. Factor analysis of the occult practices scale

\begin{tabular}{|l|c|}
\hline \multicolumn{1}{|c|}{ Varijabla } & Zasićenje \\
\hline Prisustvovao/la sam vještičarenju ili vudu ceremoniji. & 0,82 \\
\hline $\begin{array}{l}\text { Prisustvovao/la sam seansi ili sastanku na kojem su se zazivali } \\
\text { duhovi mrtvih. }\end{array}$ & 0,81 \\
\hline $\begin{array}{l}\text { Posjećivao/la sam osobu koja proriče budućnost iz karata, } \\
\text { listića čaja, dlana, kristalne kugle i slično. }\end{array}$ & 0,76 \\
\hline $\begin{array}{l}\text { Igrao/la sam se s Ouija pločom za prizivanje duhova, tarot } \\
\text { kartama ili igrom Tamnice i zmajevi. }\end{array}$ & 0,72 \\
\hline
\end{tabular}

Tablica 4. Faktorska analiza skale Demonski sindrom

Table 4. Factor analysis of the demonic syndrome scale

\begin{tabular}{|l|c|}
\hline \multicolumn{1}{|c|}{ Varijabla } & Zasićenje \\
\hline $\begin{array}{l}\text { Imao/la sam osjećaj da me se neka mračna sila dočepala i } \\
\text { prisilila me da radim loše stvari koje nisam htio/htjela. }\end{array}$ & 0,90 \\
\hline Osjetio/la sam kao da se neke mračne sile kreću unutar mene. & 0,83 \\
\hline $\begin{array}{l}\text { Osjetio/la sam prisutnost zla koje upravlja mojim životom i } \\
\text { utječe na moje misli i ponašanje. }\end{array}$ & 0,80 \\
\hline Osjetio/la sam da je neko zlo povezano sa mnom. & 0,80 \\
\hline
\end{tabular}

Za mjerenje mračne trijade korištena je kratka skala mračne trijade (SD3) (Jones i Paulhus, 2014) kojom se ispituje mračna trijada na tri dimenzije ili subskale: makijavelizam, narcizam i psihopatija. Skala se sastoji od 27 tvrdnji ili čestica (za svaku dimenziju po 9 čestica). Ispitanici su trebali izraziti stupanj slaganja sa svakom navedenom tvrdnjom koristeći skalu Likertova formata od ukupno sedam stupnjeva: 1 = uopće se ne slažem, $2=$ ne slažem se, $3=$ donekle se slažem, $4=$ niti se slažem niti se ne slažem, $5=$ donekle se slažem, $6=$ slažem se i 7 = potpuno se slažem. Subskale mračne trijade (SD3) tretirali smo kao kompozitne varijable kako bi bile usporedive s izvornim konstruktom (Jones i Paulhus, 2014). U Tablici 5 vidimo da su kompozitne subskale i cijela skala mračne trijade ličnosti (SD3) unutarnje pouzdani i homogeni mjerni instrumenti.

Tablica 5. Pouzdanost i homogenost subskala i cijele skale Mračna trijada Table 5. Reliability and homogeneity of the entire Dark Triad scale and subscales

\begin{tabular}{|l|c|c|c|}
\hline \multicolumn{1}{|c|}{ Mračna trijada } & $\begin{array}{c}\text { Cronbachova alfa } \\
\text { čestica }\end{array}$ & $\begin{array}{c}\text { Prosječna } \\
\text { interkorelacija }\end{array}$ & Broj čestica \\
\hline Makijavelizam & 0,83 & 0,34 & 9 \\
\hline Narcizam & 0,77 & 0,22 & 9 \\
\hline Psihopatija & 0,78 & 0,30 & 9 \\
\hline Mračna trijada (SD3) & 0,89 & 0,23 & 27 \\
\hline
\end{tabular}




\section{Rezultati}

\subsection{Korelacije između Okultnih praksi, Demonskoga sindroma $i$ Mračne trijade na cijelom uzorku}

Pearsonovim bivarijatnim korelacijskim analizama utvrdili smo da se okultne prakse nalaze u pozitivnim i statistički bitnim korelacijama sa svim dimenzijama mračne trijade, a među njima najviše sa psihopatijom (Tablica 6). Demonski sindrom znatno je slabije povezan s dimenzijama mračne trijade. Tek je na granici statističke značajnosti povezan s narcizmom i psihopatijom, a s makijavelizmom nije ni u kakvoj korelaciji. Dodatni nalaz koji govori u prilog da se mračna trijada ličnosti nalazi u znatno većoj mjeri u pozadini okultnih praksi ogleda se u veličini korelacija između cijele skale mračne trijade (SD3) i skale kojima se mjere okultne prakse i demonski sindrom. ${ }^{7}$ Korelacija između mračne trijade (SD3) i okultne prakse iznosi $r=0,33(\mathrm{p}<0,001)$, a korelacija između mračne trijade (SD3) i demonskoga sindroma nalazi se na granici statističke značajnosti $(r=0,15, \mathrm{p}=$ 0,04). Taj nalaz upućuje na činjenicu da se psihološka pozadina okultnih praksi u bitnoj mjeri razlikuje od psihološke pozadine demonskoga sindroma, barem kad su u pitanju dimenzije mračne trijade.

Tablica 6. Korelacije između Okultne prakse, Demonskoga sindroma i dimenzija Mračne trijade $(\mathrm{N}=189)$

Figure 6. Correlation between occult practices, the demonic syndrome and the Dark Triad dimension $(N=189)$

\begin{tabular}{|l|l|l|l|l|l|c|}
\hline & $\begin{array}{c}\text { Okultne } \\
\text { prakse }\end{array}$ & $\begin{array}{c}\text { Demonski } \\
\text { sindrom }\end{array}$ & $\begin{array}{l}\text { Makija- } \\
\text { velizam }\end{array}$ & Narcizam & Psihopatija & SD3 \\
\hline Okultne prakse & 1,00 & & & & & $0,33^{* * *}$ \\
\hline $\begin{array}{l}\text { Demonski } \\
\text { sindrom }\end{array}$ & $0,57^{* * *}$ & 1,00 & & & & $0,15^{*}$ \\
\hline Makijavelizam & $0,24^{* *}$ & 0,09 & 1,00 & & & $0,83^{* * *}$ \\
\hline Narcizam & $0,25^{* *}$ & $0,15^{*}$ & $0,40^{* * *}$ & 1,00 & & $0,78^{* * *}$ \\
\hline Psihopatija & $0,31^{* * *}$ & $0,14^{*}$ & $0,63^{* * *}$ & $0,56^{* * *}$ & 1,00 & $0,87^{* * *}$ \\
\hline
\end{tabular}

$* \mathrm{p}<0,05 * * \mathrm{p}<0,01 * * * \mathrm{p}<0,001$

7 Imajući u vidu supstancijalnu povezanost između pojedinih dimenzija mračne trijade, smatrali smo opravdanim koncept mračne trijade tretirati kao jednodimenzionalnu kompozitnu varijablu. $\mathrm{U}$ prilog tomu nam govore izrazito visoke korelacije između cijele skale SD3 s makijavelizmom ( $\mathrm{r}$ $=0,83)$, narcizmom $(r=0,78)$ i psihopatijom $(r=0,87)$. Zbog toga smo u daljnjoj multivarijatnoj analizi podataka koristili cijelu skalu SD3 kao jednu kompozitnu varijablu. 


\section{Rasprava}

\subsection{Okultno i demonsko}

U ovom smo istraživanju nastojali ispitati povezanost između Okultnih praksi i Demonskog sindroma te povezanost dimenzija Mračne trijade ličnosti s Okultnim praksama i Demonskim sindromom. Utvrdili smo da se Okultne prakse i Demonski sindrom nalaze u međusobnoj substancijalnoj korelaciji. Postoji dakle izrazita vjerojatnost da će oni koji su se bavili okultnim praksama radi stjecanja okultnih moći i znanja u većoj mjeri izražavati subjektivan osjećaj demonske prisutnosti i kontrole. Premda korelacijska analiza ne pretpostavlja uzročno-posljedičnu vezu među pojavama, možemo ipak reći, referirajući se na različita iskustva egzorcista i osoba u službi oslobađanja, da prakticiranje vračanja, magije, spiritizma i prizivanje duhova generira subjektivni doživljaj prisutnosti Zla i mračnih sila koje kontroliraju život pojedinca, implicirajući time prisutnost demonskoga tlačenja (Amorth, 2006, 128-129; Hunter, 2015, 16-17).

Međutim, veličina utvrđene korelacije između okultnih praksi i demonskoga sindroma $(\mathrm{r}=0,57)$ i koeficijent determinacije koji ukazuje da okultne prakse i demonski sindrom imaju 32\% zajedničkih vrijednosti, dokaz je da uzrok subjektivnoga osjećaja demonske prisutnosti i kontrole $u$ životu pojedinca ne mora nužno biti posljedica bavljenjem okultnih praksi. Na temelju psihološko-psihijatrijskoga značenja demonskoga sindroma možemo zaključiti kako je riječ o jednom psihopatološkom sindromu koji može imati različitu etiologiju. Takav psihološko-psihijatrijski sindrom može se povezati s disocijativnim poremećajem identiteta kad osoba ima doživljaj prisutnosti »nekoga spiritualnoga bića«, da je postala promatrač »postupaka za koje se može osjećati bespomoćna da ih prekine «, čuje glasove bića »nad kojima osoba doživljava da nema kontrolu«, pojavljuju se emocije, porivi i ponašanje »a da osoba nema osjećaj da su vlastiti i da njima upravlja « jer je »natprirodno biće [...] izvan osobe preuzelo kontrolu« (Američka psihijatrijska udruga, 2014, 293).

Određeni dijagnostički kriteriji shizotipnoga poremećaja mogli bi također korespondirati s psihološko-psihijatrijskim značenjem demonskoga sindroma. To bi se posebno moglo odnositi na tzv. pozitivnu shizotipiju, koja se odnosi na neobična perceptivna iskustva i magična vjerovanja (Lin et al., 2013, 174), na prisutnost nadnaravnih iskustava (Kwapil et al., 2017, 210) ili na zaokupljenost paranormalnim pojavama (Američka psihijatrijska udruga, 2014, 656). Mogla bi se stoga na teorijskoj razini pretpostaviti mogućnost određenoga preklapanja disocijativnoga poremećaja identiteta i shizotipnoga poremećaja u funkciji različitih dimenzija okultnih praksi i doživljaja. Imajući na umu psihopatološko značenje demonskoga sindroma generiranoga na temelju bavljenja okultnim praksama i visine povezanosti između okultnih praksi i demonskoga sindroma, možemo zaključiti da postoji okultno posredovani obrazac duševnoga poremećaja koji se manifestira u subjektivnom osje- 
ćaju demonske prisutnosti, utjecaja i kontrole. ${ }^{8}$ Time je potvrđena prva hipoteza o povezanosti okultnih praksi i demonskoga sindroma.

\subsection{Mračna trijada, okultno i demonsko}

Korelacijske analize pokazale su da su sve tri dimenzije mračne trijade u većoj mjeri povezane s okultnim praksama negoli s demonskim sindromom. Najveća povezanost postoji između okultnih praksi i psihopatije, koja predstavlja najzlokobniju crtu ličnosti u mračnoj trijadi, kojom se mogu objasniti različiti oblici zlokobnoga ponašanja i koja je povezana s različitim negativnim psihosocijalnim ishodima (Muris et al., 2017, 195). Povezanost okultnih praksi s makijavelizmom i narcizmom, pored psihopatije, upućuje na zlokobnost karaktera osobe koja se bavi okultnim praksama, odnosno njima se podvrgava. Utvrdili smo dakle da osobe koje se podvrgavaju okultnim praksama jesu u određenoj mjeri manipulativne i dvolične u međuljudskim odnosima i snažno usmjerene prema vlastitom interesu i probitku (Jones i Paulhus, 2009, 97-99), imaju osjećaj vlastite veličine i superiornosti, izražavaju potrebu za dominacijom, ohole su i egocentrične, nemaju empatiju prema drugima ni grižnju savjesti, osvetoljubive su, sklone rizičnomu ponašanju, imaju snažnu potrebu za podražajima, nisu u mogućnosti kontrolirati vlastite impulse i emocionalno su hladne osobe (Muris et al., 2017, 184). Ukratko rečeno, pojedinci koje se bave okultnim praksama mogu biti zlokobne i destruktivne ličnosti (Jones i Paulhus, 2014, 28), sklone varanju, neiskrenosti, nepoštenju i oholosti (Lee i Ashton, 2014, 2-5). S druge strane smo vidjeli da je demonski sindrom veoma slabo ili nikako povezan s dimenzijama mračne trijade, što nedvojbeno upućuje na to da se u psihološkoj pozadini demonskoga sindroma nalaze različite crte ličnosti. Okultne prakse u psihološkoj pozadini imaju egocentričnu, manipulativnu i agresivnu ličnost, a u pozadini demonskoga sindroma mogli bi se nalaziti znatno ozbiljniji duševni i duhovni poremećaji. Time je samo djelomično potvrđena druga hipoteza ovoga istraživanja o povezanosti dimenzija mračne trijade, okultnih praksi i demonskoga sindroma. Pokazalo se naime da demonski sindrom nije bitnije povezan s dimenzijama ili cijelom skalom mračne trijade.

8 Premda istraživanje nije provedeno na reprezentativnom uzorku Hrvata u Vojvodini, zanimljivo je pogledati prevalenciju nekih simptoma u strukturi demonskoga sindroma. Zbrojili smo odgovore "rijetko", "ponekad", "često" i "veoma često" na pitanje "Koliko ste često osjećali sljedeće stvari”, a koje se odnose na prisutnost zlih duhova i njihovu kontrolu. Na taj smo način formirali kategoriju odgovora: "Da, osjetio/la je prisutnost zloga." Iznenadio nas je nalaz da čak 23,5\% ispitanika odgovora da su osjetili prisutnost zla koje upravlja njihovim životom i utječe na njihove misli i ponašanje u različitom intenzitetu. Dakle, skoro svaki četvrti ispitanik imao je subjektivno iskustvo demonske prisutnosti i kontrole. Oko 11,8\% ispitanika imalo je osjećaj da ih se neka mračna sila dočepala i prisilila ih da rade loše stvari koje nisu htjeli. Generalno je manji broj ispitanika koji su se bavili okultnim praksama u odnosu na broj onih koji su imali doživljaje demonske prisutnosti i kontrole. Svakako je indikativan podatak da je oko $15,5 \%$ ispitanika bilo u kontaktu s osobom koja se bavi vračanjem. 


\section{Zaključak}

U ovom empirijskom istraživanju utvrdili smo postojanje obrasca duševnoga poremećaja čija se etiologija jednim dijelom nalazi u bavljenju okultnim praksama. Taj tip duševnoga poremećaja nazvali smo demonski sindrom jer njegova klinička slika upućuje na postojanje subjektivnoga doživljaja i iskustva demonskoga djelovanja, utjecaja, kontrole i zarobljenosti. Simptomi demonskoga sindroma u određenoj mjeri korespondiraju s opisom pojedinih dijagnostičkih obilježja disocijativnoga poremećaja identiteta i shizotipnoga poremećaja ličnosti. Ovim je istraživanjem popunjena praznina koja postoji u akademskim istraživanjima koja se odnose na povezanosti okultnih praksi i onoga duševnoga poremećaja u čijoj se psihološkoj pozadini nalazi jasno artikulirani subjektivni osjećaj i iskustvo demonske prisutnosti. Ipak, veličina korelacije i koeficijent determinacije nedvosmisleno ukazuju na mogućnosti drugačije etiologije demonskoga sindroma. U psihološkoj se pozadini okultnih praksi nalazi zlokobni karakter, a u pozadini demonskoga sindroma nalazi se psihijatrijski i duhovni poremećaj. U takvim je slučajevima teško odrediti dijagnozu bez zajedničke suradnje psihijatra i svećenika. Katolički svećenici trebali bi u svojem pastoralnom djelovanju biti svjesniji kako psihičke i duhovne patnje, zbog kojih im se ponekad vjernici obraćaju, ne moraju biti samo medicinske, psihološke ili socijalne, nego i demonske naravi. S druge pak strane, psihijatrima se može sugerirati da pitaju pacijenta je li sudjelovao osobno, ili netko od njegove rodbine, u okultnim praksama kako bi imao eventualno drugačiju osnovu za razumijevanje duševnoga poremećaja.

Ovdje možemo navesti i nekoliko ograničenja koje ima ovo istraživanje. Prvo, uzorak je relativno mali s obzirom da je riječ o ispitivanju socijalno devijantnoga oblika ponašanja kao što je bavljenje okultnim praksama i ozbiljnom duševnom poremećaju koji ukazuje na postojanje subjektivnih osjećaja i iskustva demonske prisutnosti, utjecaja, kontrole i zarobljenosti. Drugo, nedostajale su skale za direktno mjerenje potrebe za okultnim znanjem i težnje za okultnom moći kako bi se preciznije mogli definirati motivacijski sklopovi ulaženja u svijet okultnoga. I treće, istraživanjem nisu bile obuhvaćene one baterije psiholoških i psihijatrijskih testova koje bi mogle biti od važnosti u objašnjenju demonskoga sindroma. Stoga predlažemo da se u nekom budućem istraživanju konstruira višedimenzionalna skala okultnih praksi koja bi sadržavala i motivacijske referentne okvire bavljenja okultnim praksama. Radi jasnijega teorijskoga postavljanja i empirijske provjere koju imaju okultne prakse i demonski sindrom u etiologiji duševnih poremećaja, predlažemo formiranje teorijskoga strukturalnoga modela kojega će definirati traume u djetinjstvu, okultno-demonski obrasci i duševni poremećaji. U tako postavljenom teorijskom modelu gdje traume u djetinjstvu imaju glavni etiološki značaj u razvitku duševnih poremećaja, okultno-demonski obrasci imali bi značenje medijacijske varijable između traumatskih iskustva u djetinjstvu i duševnih poremećaja. Možemo naime prihvatiti da traumatska iskustva u djetinjstvu imaju uzročnu ulogu u etiologiji duševnih poremećaja, ali je pitanje što se događa u odnosima između traumatskoga iskustva u djetinjstvu i duševnih poremećaja kada 
varijablu okultno-demonsko uvedemo u ovaj model. Naime, povezanost između traumatskih događaja u djetinjstvu i duševnih poremećaja može nestati ili se u bitnoj mjeri smanjiti kad se okultno-demonsko uvede kao kovarijacija u analizu. To bi značilo da su povezanosti između trauma u djetinjstvu i duševnih poremećaja posredovane određenim okultno-demonskim obrascem. Takvo istraživanje trebalo bi provesti na uzorku izvanbolničkih psihijatrijskih pacijenata.

\section{Literatura:}

American Psychiatric Association (52013). Diagnostic and Statistical Manual of Mental Disorders. Washington, DC: American Psychiatric Association.

Američka psihijatrijska udruga (2014). Dijagnostički i statistički priručnik za duševne poremećaje: Peto izdanje: DSM-5. Jastrebarsko: Naklada Slap.

Amorth, Gabriele (2005). Egzorcisti i psihijatri. Jelsa: B. Medvid.

Amorth, Gabriele (2006). Izvješća rimskog egzorcista. akovo: Karitativni fond UPT.

Azizli, Nicole; Atkinson, Breanna E.; Baughman, Holly M.; Chin, Kristi; Vernon, Philip A.; Harris, Elizabeth; Veselka, Livia (2016). Lies and crimes: Dark Triad, misconduct, and high-stakes deception. Personality and Individual Differences, 89 (January), 34-39.

Campos, S. R. (2018). The Fine Line Between Demonic Influence and Illnesses. Pittsburgh: Dorrance.

Fortea, José Antonio (2018). Summa daemoniaca: Traktat o demonologiji i Priručnik o egzorcizmu. Velika Gorica: Naklada Benedikta.

Hunter, Jack (2015). "Between Realness and Unrealness": Anthropology, Parapsychology and the Ontology of Non-Ordinary Realities. Diskus: The Journal of the British Association for the Study of Religions, 17(2), 4-20.

Immanuel, Stella (2016). Deliverance program packet. Alexandria LA: Fire Power Ministry. URL: http:/firepowerministry.org/blog/?p=1918 (28.03.2019.)

Jeanguenin, Gilles (2010). Sotona i njegove zamke: Egzorcist svjedoči i odgovara na pitanja o demonima, opsjednuću, urocima... Split: Verbum.

Jones, Daniel N.; Paulhus, Delroy L. (2009). Machiavellianism. U: Mark R. Leary i Rick H. Hoyle (ur.), Handbook of individual differences in social behavior (str. 93-108). New York: Guildford.

Jones, Daniel N.; Paulhus, Delroy L. (2014). Introducing the Short Dark Triad (SD3): A brief measure of dark personality traits. Assessment, 2(1), 28-41.

Kwapil, Thomas R.; Gross, Georgina M.; Silvia, Paul J.; Raulin, Michael L.; BarrantesVidal, Neus (2017). Development and psychometric properties of the Multidimenional Schizotypy Scale: A new measure for assessing positive, negative, and disorganized schizotypy. Schizophrenia Reserach, 193 (March), 209-217.

Lee, Kibeom; Ashton, Michael C. (2014). The Dark Triad, the Big Five, and the HEXACO model. Personality and Individual Differences, 67 (September), 2-5.

Lin, Ashleigh; Wigman, Johanna T. W.; Nelson, Barnaby; Wood, Stephen J., Vollebergh, Wilma A. M.; Os, Jim van; Yung, Alison R. (2013). Follow-up factor structure of schizotypy and its clinical associations in help-seeking sample meeting ultra-high risk for psychosis criteria at baseline. Comprehensive Psychiatry, 54(2), 173-180.

MacNutt, Francis (2005). Oslobođenje od zlih duhova. Zagreb: Pokret krunice za obraćenje i mir. 
Mezzetti, Tarcisio (2016). “...kao ričući lav...”: Zlo opsjeda Božji narod. Velika Gorica: Naklada Benedikta.

Morabito, Simone (2015). Psihijatar u paklu: Znanstveno izvješće. Velika Gorica: Naklada Benedikta.

Muris, Peter; Merckelbach, Harald; Otgaar, Henry; Meijer, Ewout (2017). The malevolent side of human nature: A meta-analysis on the Dark Triad (Narcissism, Machiavellianism, and Psychopathy. Perspectives on Psychological Science, 22(2), 183-204.

Nie, Fanhao; Daniel V. A. Olson (2016). Demonic influence: The negative mental health effects of belief in demons. Journal of the Scientific Study of Religion, 55(3), 498-515.

Paulhus, Delroy L.; Williams, Kevin M. (2002). The Dark Triad of personality: Narcissism, Machiavellieanism and Psychopathy. Journal of Personality, 36(6), 556-563.

Occult Practices, the Demonic Syndrome and the Dark Triad of Personality

Zlatko Šram*

\section{Summary}

This research is the first attempt to investigate empirically (a) the link between occult practices and the demonic syndrome and (b) the link between the Dark Triad of personality (Machiavellianism, narcissism, and psychopathy) and occult practices and the demonic syndrome. The survey was carried out on a random sample of Croats $(N=189)$ living in the Autonomous Province of Vojvodina (Republic of Serbia). The scales measuring both occult practices and the demonic syndrome were developed for the purpose of this research. Factor analysis showed the construct validity of the scales that were proven to be reliable and homogenous measuring instruments. The Dark Triad was measured by the Short Dark Triad (SD3) (Jones \& Paulhus, 2014). It was found that occult practices and the demonic syndrome were substantially correlated $(r=0.57)$. All three dimensions of the Dark Triad were in much stronger correlation with occult practices than the demonic syndrome. We found that the existence of mental disorder manifested in the subjective feelings and experiences of a demonic presence, influence, and control is a result of dabbling in the occult. Manipulativeness, egocentricity and lack of empathy are the traits of a person inclined to engage in occult practices. It is supposed that there are different and more serious mental disorders underlying the demonic syndrome.

Key words: occult practices, demonic syndrome, mental disorders, the Dark Triad, Croats in Vojvodina

* Zlatko Šram, Ph. D., Senior Research Associate, Croatian Center for Applied Social Research. Address: Hanamanova 7, 10000 Zagreb. E-mail: zlatko.sram@appliedsocresearch.com 